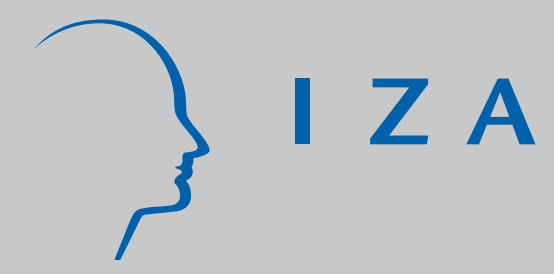

IZA DP No. 2502

Educational Inputs and Outcomes

Before the Transition from Communism

J ohn Beirne

Nauro F. Campos

December 2006 


\title{
Educational Inputs and Outcomes Before the Transition from Communism
}

\author{
John Beirne \\ Brunel University \\ Nauro F. Campos \\ Brunel University, CEPR \\ and IZA Bonn
}

\section{Discussion Paper No. 2502 \\ December 2006}

\author{
IZA \\ P.O. Box 7240 \\ 53072 Bonn \\ Germany \\ Phone: +49-228-3894-0 \\ Fax: +49-228-3894-180 \\ E-mail: iza@iza.org
}

\begin{abstract}
Any opinions expressed here are those of the author(s) and not those of the institute. Research disseminated by IZA may include views on policy, but the institute itself takes no institutional policy positions.
\end{abstract}

The Institute for the Study of Labor (IZA) in Bonn is a local and virtual international research center and a place of communication between science, politics and business. IZA is an independent nonprofit company supported by Deutsche Post World Net. The center is associated with the University of Bonn and offers a stimulating research environment through its research networks, research support, and visitors and doctoral programs. IZA engages in (i) original and internationally competitive research in all fields of labor economics, (ii) development of policy concepts, and (iii) dissemination of research results and concepts to the interested public.

IZA Discussion Papers often represent preliminary work and are circulated to encourage discussion. Citation of such a paper should account for its provisional character. A revised version may be available directly from the author. 
IZA Discussion Paper No. 2502

December 2006

\section{ABSTRACT}

\section{Educational Inputs and Outcomes Before the Transition from Communism*}

Conventional wisdom suggests that the stocks of human capital were one of the few positive legacies from communism. However, if factories under communism were so inefficient, why would the education system not have been? Using the education production function approach and new data on educational inputs and outcomes from 1960 to 1989, we find evidence suggesting that the official human capital stocks figures were "over-estimated" during the communist period. In other words, we find that the official human capital stock numbers are significantly higher than those predicted not only in relation to countries at similar levels of development, but also on the basis of educational systems with comparable features and efficiency levels.

JEL Classification: $\quad$ O11, J24, P27, P39

Keywords: $\quad$ human capital, education, transition economies

Corresponding author:

Nauro F. Campos

Department of Economics and Finance

Brunel University

Uxbridge, Middlesex UB8 3PH

United Kingdom

E-mail: Nauro.Campos@brunel.ac.uk

\footnotetext{
We thank Yael Duthilheul, Randall Filer, Stepan Jurajda, Michal Kejak, Daniel Munich, Jeffrey Nugent, Viatcheslav Vinogradov and an anonymous referee for valuable comments. Rodica Cnobloch provided superb research assistance. This research was made possible by a grant from The Spencer Foundation (Chicago, USA). Campos also would like to thank the Bank of Finland Institute for Economies in Transition (BOFIT) for the hospitality and the excellent research environment which were instrumental in the preparation of the final revision. The usual disclaimer applies. The data set constructed for this paper is available from the authors upon request.
} 


\section{Introduction}

Conventional wisdom suggests that if there is one area where the countries of Eastern Europe and the former Soviet Union are well served it is with respect to their stocks of human capital. Most human capital indicators (for instance, gross and net enrollment rates, average years of schooling and literacy levels) tend to be better in the late 1980s for these countries than for, say, the members of the OECD. A number of developments in growth theory, however, stress that human capital creates positive externalities, that physical capital does not flow to poor countries because they lack the needed complementary human capital, and that human capital matters because it gives greater adaptability to a labor force. ${ }^{1}$ From this point of view, abundant high-quality human capital is a sine qua non for economic growth. Some surprising puzzles emerge when we stack up these theoretical predictions against the experience of the transition economies, as shown by their erratic growth rates, the stagnant pool of unemployment that emerged in many countries and the volatile behavior of foreign direct investment in this period.

The aim of this paper is to try to re-think human capital accumulation during communism. One way to motivate this task is to consider that if communist factories were highly inefficient, why would the schooling system not be? Why should we expect education production not to obey central planning directives? Another way to think about this issue is to consider the possibility of a few parallels with the stock of physical capital. The latter was widely regarded as inadequate because of out-dated technology and demand shifting from defense to consumer goods. In a similar fashion, one can imagine that many skills were outdated and that the educational system for far too long inhibited individual creativity, the stuff

\footnotetext{
${ }^{1}$ These arguments can be found in, among others, Schultz (1961, 1975), Nelson and Phelps (1966), Easterlin (1981), and Lucas (1988, 1990). Schultz argues, appropriately, that to omit human capital from "studying economic growth is like trying to explain Soviet ideology without Marx" (1961, p. 3).
} 
of entrepreneurship. ${ }^{2}$ Some of these concerns have been identified in the literature. For instance, Boeri (2000) argues that the well-known excessive specialization of socialist educational systems is a major cause of the lack of flexibility evident in the labor force. Gundlach (2001) argues that an important factor explaining the relative poor performance of the former East Germany, vis-à-vis West Germany, is the quality of human capital stocks. Campos and Dabusinskas (2003) argue that the occupational structure inherited from communism is inadequate to the needs of a modern market economy: there are too many rocket scientists and not enough marketing clerks.

The objective of this paper is to use the theoretical and empirical underpinnings provided by the education production function approach (Hanushek, 1979, 1986) to compare predicted and actual educational outcomes for a large sample of countries (developed, developing and transition) from 1960 to 1989 . More precisely, we investigate whether the predicted value of various educational outcomes (such as educational attainment or average years of schooling in the work force) are significantly different in the former socialist countries than in and the rest of the world. These are estimated on the basis of a vector of educational "inputs" (such as pupil-teacher ratio, teacher salaries, public expenditure on education and repetition rates). In order to apply this method, we constructed a unique data set on educational inputs and outcomes for the countries of the former Socialist Bloc as well as for a large number of developed and developing countries (from 1960 to 1989).

Our main findings are as follows. Our evidence shows that the human capital stocks of the formerly planned economies in Eastern Europe and the Soviet Union at the outset of the transition were over-estimated (that is, the actual average years of schooling were significantly higher than predicted) not only with respect to countries at similar levels of

\footnotetext{
${ }^{2}$ Using data for years 1994-95, Ammermuller et al. (2003) show that some transition countries were successful at quickly reforming their education systems (for instance, they contrast the Czech and Slovak Republics, Slovenia and Hungary to the situation in Latvia, Lithuania and Romania).
} 
development, but also with respect to educational systems with comparable features and levels of efficiency. Interestingly, while the literature stresses that these differences would be more prominent in the secondary education sector, in this paper we find that these differences are more prominent in the primary education sector. We recognise, of course, that pupils would "carry over" any deficiencies from primary to secondary education. Yet our results suggest that the roots of the issue seem to be very much at the primary education sector, and not at the secondary education sector as commonly argued.

The paper is organized as follows. In the next section we briefly discuss human capital issues emanating from the new growth literature that we believe are relevant to the experience of the former communist economies. Section III presents the data set we constructed for this paper. Section IV outlines the educational production function approach and discusses our estimates. Section V concludes.

\section{Useful insights from the human capital literature}

The objective of this section is to provide a brief overview of the human capital literature, stressing a few insights we deem useful for the experience of the transition economies. ${ }^{3}$ Human capital entered the economics research agenda around 1960 through the pioneering work of Mincer (1958), Schultz (1961), Becker (1964, [1993]) and Nelson and Phelps (1966). Since at least Adam Smith, economists have been concerned with education, but treating this as resulting from investment instead of purely consumption decisions is much more recent. We should also note that the original definition of human capital is broader than its customary usage. Although in this paper we follow custom and restrict our attention to formal

\footnotetext{
${ }^{3}$ For authoritative reviews, see Rosen (1986), Mincer (1996), and Aghion and Howitt (1998).
} 
education, human capital was originally thought of as also including improvements in health status, on-the-job training, "study programs for adults", and migration (Schultz, 1961). ${ }^{4}$

We highlight two recent theoretical advances in the human capital literature. The first refers to different conceptualizations of the process of human capital accumulation itself. While Mankiw, Romer and Weil (1992) postulate an identical technology for producing physical and human capital, Rebelo (1991) offers a production function for human capital that is human capital intensive, and Lucas (1988) and Azariadis and Drazen (1990) put forward a production function for human capital that contains no physical capital at all. Another related advance is the threshold externalities model constructed by Azariadis and Drazen (1990). They hypothesise that economic growth is correlated with human capital investment relative to per capita income, "with high rates of growth associated with the prior attainment of especially high levels of human capital relative to per capita income" (1990, p. 519). Also note that Lucas (1988) and Mankiw, Romer and Weil (1992) raise the important question of whether it is the level or the rate of human capital that matters for growth. ${ }^{5}$

With respect to the empirical literature, there are two advances that we need to mention. The first is the success in constructing a variety of much improved measures of human capital stocks. Moreover, these have been constructed for a large number of countries and long periods of time, often since 1960. Examples of these are Barro and Lee (1993, 1996, 2001a, 2001b) and Nehru, Swanson and Dubey (1995). Notice that the latter does not include transition or formerly centrally planned economies but they are the only human capital stock figures available, to the best of our knowledge, that are adjusted for student dropouts and

\footnotetext{
${ }^{4}$ Notice that, although this definition is rather comprehensive, it excludes "knowledge" and/or "ideas". This is an important distinction emphasized in the endogenous growth literature (Romer, 1990, 1993), inter alia, because "differences in form between human and non-human capital are of less import for analysis than are differences in the nature of property rights between them" (Rosen, 1986, p. 682).

${ }^{5}$ Murphy, Schleifer and Vishny (1991) emphasize that the most important aspect of human capital accumulation is in terms of occupational choice. In particular, how a society's pool of talent is allocated to entrepreneurial or rent-seeking activities is fulcral vis-à-vis long-term growth. A related line of research is the political economy literature, which argues that greater income inequality reduces the growth rate
} 
repetition rates (Bosca et al., 1997). In this paper, we use this intuition but instead of focusing on the predicted level of human capital stock, we focus our attention on the magnitude and direction of the discrepancies (between actual and predicted values). The second advance in the empirical literature we should mention is that, although "older" evidence showing that education matters for growth is abundant, one striking feature from the more recent empirical literature is the difficulty to provide robust evidence in a cross-national framework for the notion that education contributes positively for economic performance. ${ }^{6}$

Finally, there are a number of contributions to the literature that have attempted to raise the possibility of a problem with respect to human capital formation in transition economies. Two notable ones are Laporte and Schweitzer (1994) and the World Bank (1996). ${ }^{7}$ Despite the lack of empirical support, the arguments offered by Laporte and Schweitzer are very important in order to understand the quality of a significant fraction of today's labor force that were educated under communism. They stress the secondary school as the locus of most problems, arguing that it was marked by excessive and premature specialization and by rigid stratification. They exemplify by noting that 300 occupational skills were taught in Polish secondary schools compared to "only" 16 in West Germany. ${ }^{8}$ The second is the 1996 World Development Report that raises the issue that there is a problem

largely through its effects on the distribution of education (Persson and Tabelini, 1997).

${ }^{6}$ Pritchett (1996) presents three possible reasons for this lack of a positive contribution. First, because people acquire education mainly for signaling, not productive, purposes. Second, this may be caused by rapidly falling returns to education when demand for educated labour is stagnant (because of limited adoption of technological innovations.) A third possibility would be because education is used mostly to choose rent-seeking activities over entrepreneurial ones (as in Murphy et al., 1991). See, also Temple (2001). Note that Bils and Klenow (1997) report that causality flows from growth to education, and not the other way around. Hanushek and Kimko (2000) show that labor force quality and growth are strongly related.

${ }^{7}$ There are many other authors who mention problems in this respect but they often do this without elaborating. For example, Sachs argues that "Other key reform steps for Eastern Europe include (...) a focused long-term strategy for improvements in infrastructure and education" (1996, p. 132).

${ }^{8}$ They recognize that "it could be argued, therefore, that reforming the education and training system is not a high priority because so many urgent matters are demanding the attention of cash-strapped policy-makers and that restructuring can therefore wait. Why would such a policy of neglect be a critical mistake?" (Laporte and Schweitzer, 1994, p.260). Their answer is echoed here: inattention to such issues can be costly in terms of long-run economic growth. 
with respect to human capital formation in transition economies (Chapter 8), under the banner "is transition a killer?" The Report identifies three sources of problems. One is the excessive specialization in secondary technical schools, another is the disregard for adult education and training, and the last is the complete neglect of subjects like "economics, management science, law and psychology" (World Bank, 1996, p.124).

In summary, although the issues raised with respect to the actual quantity and quality of human capital stocks in the Eastern Europe and former Soviet Union seem sound, they are in large part unsupported by empirical evidence. The evidence brought to the fore so far seems to fall short and thus, the conventional wisdom that no problem exists seems to escape intact. In looking at human capital accumulation under communism and during the transition process, we should keep in mind that although education seems to matter, we are still far from establishing the precise mechanisms through which it does. We now have a better understanding that the accumulation processes of physical and human capital are different (the latter being distinctively human capital intensive) and, as for the contribution of human capital to growth, that quality seems to matter at least as much as quantity. ${ }^{9}$ In the next section, we apply these lessons and concerns to new data for the transition economies to investigate the existence and strength of support for our main hypothesis in this paper, namely, that their human capital stocks were over-estimated at the outset of the transition.

\section{Data and Methodology}

The objective of this section is to describe the data set and methodology used in this paper. From the outset, two caveats are in order. The first relates to data quality, ${ }^{10}$ and the second

\footnotetext{
${ }^{9}$ According to Solow: "The accumulation of human capital appears to be much more a matter of quality than of quantity. People acquire new skills rather than more of the old skill. (...) I only want to mention the possibility that the accumulation of human capital obeys rather different laws from those governing the accumulation of physical capital, in terms of its own production and perhaps in terms of its use in the production of goods" (1997, pp. 77-78).

${ }^{10}$ See Behrman and Rosenzweig (1994).
} 
refers to the limits of regional aggregation. As for the latter, we are aware that the situation in the former Soviet Union differs from the one in Eastern and Central Europe. However, looking at them jointly is important. The conventional wisdom is that one of the main differences between transition and developing countries is that the former group has much higher stocks of human capital, and consequently does not have to worry about or solve any problems in this respect.

Let us now turn to the data. The main data source is the set put together by Barro and Lee $(1993,1996,2001 \mathrm{a}, 2001 \mathrm{~b})$. This is a set of internationally comparable data that includes information on both the outcomes of and the inputs into the education sector. However, few socialist economies are included (and further, for those included, little actual data exist in the database). Therefore, a major effort was conducted to fill in these missing observations. In what follows, we will discuss some of the "outcome" and "input" variables upon which our empirical analysis is based.

The sample of former centrally planned economies comprises the following countries: Albania, Bulgaria, Czechoslovakia, East Germany, Hungary, Poland, Romania, Soviet Union and Yugoslavia. The resulting dataset is unique and provides a useful source of educationrelated data for transition economies. ${ }^{11}$ Outcome variables include average years of schooling in the population (primary and secondary), and proportion of schooling attained and completed by the population (primary and secondary). Input variables include pupil-teacher ratios at primary and at secondary school, real government educational expenditures per pupil at primary and at secondary school, average real salary of primary school teachers, repetition rate at primary school and at secondary school (in percentage), drop-out rate at primary school (in percentage), number of school days and hours per year at primary school. ${ }^{12}$

\footnotetext{
${ }^{11}$ It is our view that the unique data set we put together for this paper can also be useful in future research as it provides a (largely untapped) set of instrumental variables.

${ }^{12}$ The basic source of data for the former socialist economies is the UNESCO Statistical Yearbooks (1961, 1966, 1971, 1976, 1981, 1986, 1991, and 1996), although heavily supplemented by national sources (e.g.,
} 
In what follows, we provide a brief overview of the data we put together for this paper. Our analysis of the raw data shows the main basis for the conventional wisdom. Relevant data are available for 1960 onwards, and since 1965 the now formerly planned economies as a group exhibit a larger stock of human capital than any other region in the world. It is noteworthy that for the later years these are clearly larger than the stocks in the OECD countries (Figure 1).

An important "input" variable is government expenditures per pupil at primary (Figure 2) and secondary (Figure 3) school. The series constructed for this paper is real public educational expenditure per student at primary and secondary school, in PPP adjusted 1985 dollars. Because data on price levels or exchange rates was unavailable, it was not possible to construct this variable for Albania, Bulgaria (1960-1980), DDR (1960 and 1965), Hungary (1960 and 1965), and Poland (1960 and 1965). It is important to note that for some countries (mainly in the earlier years) government expenditures were given only for total primary and secondary education so we had to assume that the distribution of the expenditures among different types of education remain unchanged until 1990. In terms of the evolution of real public educational expenditure per pupil at primary school over time, there seems to be a clear increasing trend. Africa seems to be the exception, as these expenditures actually decline over time. Usually, these values for Africa, Asia, Latin America, and Middle East and North Africa are less than $\$ 400$. The transition and the OECD economies have values above $\$ 500$ around 1960 that increase to $\$ 2700$ (OECD) and \$2000 (transition) around 1990. The trend for the OECD is mostly increasing, while for the transition economies it is so only for the period 1965-1985.

Czechoslovak Statistical Office, various issues, German Democratic Republic Statistical Office, various issues, Romanian Statistical Office, various issues, USSR Statistical Office, various issues). We are grateful to two data depositories in the region (namely, the CEU Archive in Budapest and the CERGE-EI library in Prague) for granting us access to hard-to-find primary sources. 
Regarding the evolution of real public educational expenditures per student in secondary school, in PPP adjusted 1985 dollars, there seems to be no clear trend in our data. For the transition group, these expenditures are increasing until 1980 (from $\$ 1400$ to $\$ 4000$ ), followed by a big decline in 1985 (to $\$ 1100$ ) and arriving in 1990 at a similar level as that observed in 1960. Interestingly, until 1970, expenditures in transition economies were much larger than in the rest of the developing world, as well as larger than in OECD countries.

As for dropout rates, for the transition group the values are in the range of 5 to 10 percent, increasing over time, except for the period 1976-1980. Also, the OECD and transition groups are the only groups with single-digit dropout rates throughout the period, with all others showing higher rates. Still, the OECD group has smaller dropout rates than the transition group (and for the OECD, these are almost constant, at around 3\%).

Figures 4 and 5 show repetition rates at primary and secondary education. These rates are clearly lower for the transition economies. It may well be the case that the logic and requirements of the central planning system are at play in keeping repetition rates low. This maybe driven by the system specifying the number of, say, engineers and lawyers needed each year, giving the education sector little latitude and at the same time providing it with the incentive to "over-report" output. Moreover, the rigid stratification that many believe characterized the educational system in these countries adds to this point in light of the fact that requirements for graduation at such a diverse number of tracks (recall the 300 in Poland versus 16 in Germany) should be far from the same. If these rates are in this sense artificially low, the stock figures will be biased upwards (in comparison to all other groups of countries we have been considering thus far) because a relatively smaller fraction of students repeat.

In summary, we find that the outcomes for general education (percentage of no schooling and the average years of schooling) and for primary school (attained, completed and average years of primary school) are indeed better among the transition countries than 
among OECD economies (as well as than for any other regional group). As for inputs, they are often better in the transition than in the other groups. At the primary school level, in the formerly centrally planned economies there are small drop-out rates which are decreasing over time. Teacher-pupil ratios and repetition rates are also decreasing (and sometimes are the lowest in transition countries). Government educational expenditures per pupil at primary school are sometimes larger in transition countries than for the OECD, but definitely larger than for all other groups. Notice also that teachers' salaries decrease over time and the ratio of these salaries to real per capita GDP decreases sharply over time in the transition group. Regarding secondary education, on one hand, there are small repetition rates in the formerly centrally planned economies and the pupil/teacher ratios are the highest after the OECD. On the other, public expenditures per pupil, after an initial increase, fall and do not recover.

Let us turn to the methodology. The methodology used here follows the approach pioneered by Hanushek $(1979,1986)$ and consists of "educational production functions", with which we can analyze the effect of inputs and outcomes to the process of education. This approach holds that the output of the educational process is directly related to the inputs. We have already described the output and the input variables for consideration in this study. A further important factor to bear in mind is that education production functions are able to capture the fact that although outputs tend to be discrete in nature, inputs can have a cumulative effect over time, whereby lagged inputs can influence current output. ${ }^{13}$

An education production function model follows the form (Hanushek, 1979):

$$
A_{i t}=f\left(B_{i}^{(t)}, S_{i}^{(t)}, P_{i}^{(t)}, I_{i}\right)
$$

where $A_{i t}$ represents the achievement of student $i$ in year $t, B_{i}^{(t)}$ is a vector of background characteristics of the student cumulative to time $t, S_{i}{ }^{(t)}$ is a vector of school inputs cumulative 
to time $t, P_{i}{ }^{(t)}$ is a vector of peer-group effects cumulative to time $t$, and $I_{i}$ is a vector of the innate abilities of the student.

The application of the model above in an empirical context would be quite complex given the uncertainty regarding the rate at which inputs affect output over time. The basic idea is the educational system produces human capital, using a technology of production that is a certain way of combining different inputs. With this in mind, Hanushek (1979) has provided an alternative to the model above, as follows:

$$
A_{i t}=f^{*}\left(B_{i}^{\left(t-t^{*}\right)}, S_{i}^{\left(t-t^{*}\right)}, P_{i}^{\left(t-t^{*}\right)}, I_{i}, A_{i t^{*}}\right)
$$

This version of the model enables us to consider the change in outcomes and inputs over the period from to $t^{*}$, and this is the type of model typically estimated using the education production function approach.

Our central concern in this paper is to test whether the available figures for the human capital stocks of the transition economies are over-estimated. The method we select to investigate this possibility is as follows. We first run one specification of the education production function, using OLS on pooled data. We then calculate the average residual for each region. Mainly we restrict our attention to three groups: transition, OECD and the "rest." ${ }^{14}$ Finally, we test whether the difference between the transition group residual and the OECD group residual is statistically significant, and whether the difference between the transition group residual and the "rest" group residual is also statistically significant. We then repeat this analysis at a more disaggregated level by breaking down the "rest of the world" category into Africa, Asia and Latin America sub-samples.

\footnotetext{
${ }^{13}$ For a discussion see Card and Krueger (1996), and Pritchett and Filmer (1997).

${ }^{14}$ The "rest" group is admittedly broad, yet justified by our objectives as well as the data description in the previous sections (which shows that the OECD and pre-transition educational systems are apparently
} 


\section{Results}

In this section, we discuss our main econometric results using the "education production function" approach (Hanushek, 1979, 1986). ${ }^{15}$ Tables 1 to 4 report estimates of the education production function at the primary and secondary level. If there is over-estimation of the stocks of human capital, this should be reflected in the first instance in the average regional residuals. Accordingly, these should be positive for the transition group. Such overestimation should also show in that the average residuals for the transition group should be larger than the average residuals for the other regions such that their difference is statistically significant. We examine the average residuals across six regional groups, namely transition economies, OECD countries, Africa, Asia, Latin America, and "rest" (which is comprised of Africa, Asia and Latin America).

Table 1 sets out the results of education production functions pertaining to primary schooling. We report three main specifications, each with a different dependent variable. In the first set of results the dependent variable is average years of primary schooling in the total population older than 25 years of age (PYR25), in the second we have the percentage of primary schooling attained (PRI25) and in the third we use the percentage of primary schooling completed (PRIC25). Regarding the first specification, the signs of most of the "input" variables accord to priors. The coefficient on the number of students per teacher is always negative, indicating that the more students per teacher we have in primary school the lower the average years of primary schooling in the total population tends to be. Repetition and dropout rates are also consistently signed negative as one would expect. Teacher's salary and government expenditures on primary education are both positive and statistically 
significant. In addition, the fit of the regressions is reasonably good. In the bottom part of the tables, we report the average residuals per different regional groups originating from each specification of the education production function. It is easy to see that the transition residuals are much bigger than that of the OECD, the other three regions as well as and the "rest of the world" group and that that difference is statistically significant throughout.

Similar results are obtained when the dependent variable is changed to either PRI25 or PRIC25 (although the fit of the regressions is slightly worse). Most of the coefficients for the inputs are statistically significant and carry the expected sign. For instance, the number of students per teacher is always negative, repetition rates are also consistently negative as one would expect. The coefficient on teacher's salary is positive and statistically significant. The average residuals per different regional groups originating from each specification of the production function indicate that the transition residuals are notably larger than those of the OECD and "rest of the world" groups and that that difference is again statistically significant.

Tables 2 to 4 show our results using outcome figures for secondary education. Each table provides two regression specifications, one that includes the repetition rate variable and the other that does not. It is clear from the tables that the inclusion of repetition rate reduces the number of observations dramatically and, consequently, is influential in terms of its impact on the average residual differences between the transition group and other regional categories (and on the associated statistical significance of these differences). Yet we find this is caused largely by data availability problems with the "rest of the world" sample. ${ }^{16}$

\footnotetext{
${ }^{15}$ For a discussion see Card and Krueger (1996), and Pritchett and Filmer (1997).

${ }^{16}$ We find no qualitative difference in the results if we restrict the sample to only those observations with data on repetition rates. For instance, with "secondary school attained" as the dependent variable, the adjusted $\mathrm{R}^{2}$ for the specification including the repetition rate is 0.4685 (Table 3 ). Estimated without the repetition rate but restricting the estimation to the same observations, the adjusted $\mathrm{R}^{2}$ is 0.4544 . Similar conclusions are reached with either "average years of secondary schooling" or "secondary school complete" as the dependent variables. This is an important issue because omitted variables, if severe, would have a huge impact on our conclusions. In a nutshell, the inclusion of the repetition rate does not affect the fit of the model and the resulting differences are driven entirely by data availability issues, mainly for the African countries in our sample.
} 
Table 2 shows our results when the dependent variable (outcome) is average years of primary schooling in the total population (over 25 years). The number of students per teacher carries a negative sign and is statistically significant when the repetition rate is included. Government expenditures provide an important result in this case as it is always statistically significant and positive. Notice that the coefficient on the ratio of government expenditures to GDP is also statistically significant, but it carries an unexpected negative sign. The fit of the regressions is again quite good. In relation to the specification that incorporates the repetition rate, the average transition residual is not much bigger than those of the other regional groups, and differences are seldom statistically significant. A different picture emerges, however, when the repetition rate is excluded. In this scenario, the average transition residual is always (statistically significantly) greater than that of the other groups.

Table 3 shows the results for the specifications in which the dependent variable is the percentage of "secondary school attained" in the total population older than 25 years. Similar results are found to those in Table 2 in terms of the signs of the coefficients. For example, the ratio of government expenditures to GDP is largely statistically significant, but again carries an unexpected negative sign (while government expenditures per se are always statistically significant and positive). The fit of the regressions is reasonably good. At the bottom part of the table, we have the average residuals per different regional groups originating from each specification of the production function. It can be seen that in this table the transition residuals are much bigger than those for other groups. In fact, looking solely at the specification without repetition rates (which has almost twice the number of observations ${ }^{17}$ ), the transition residual is greater than that of all other groups. In addition, the differences in these residuals is statistically significant across all groups when the repetition rate is excluded (as opposed to mixed results in this regard for the specification with the repetition rate). 
A broadly similar pattern can be observed when the dependent variable is the percentage of "secondary school completed" in the total population, over 25 years (Table 4). It can be seen that students per teacher ratio carries a negative sign and is statistically significant. The transition residuals are much larger than those of the other regional groups (and statistically significant) only when repetition rates are excluded from the estimated regression equation.

Overall, it is clear that in the case of primary education, the average residuals for the transition economies are higher than those of all other regional groups we examine and these differences are statistically significant. Regarding secondary schooling, there is some evidence to suggest an over-estimation in the human capital stock in transition economies. Specifically, our results without the repetition rate are strong in terms of the larger average residual (and with differences always statistically significant) for the transition group vis-àvis other regions.

\section{Conclusions}

The purpose of this paper was to call attention the issue of human capital formation under communism. Using a newly constructed data set on educational inputs and outcomes for the countries of the former Socialist Bloc (from 1960 to 1989) and the education production function approach, we find evidence to suggest that the human capital stocks at the outset of the transition from plan to market were over-estimated. In other words, the average years of schooling were higher than predicted not only with respect to countries at similar levels of development, but also with respect to educational systems with comparable features and levels of efficiency. The conclusions seem to be robust in light of the majority (eight out of nine) of the transition-rest of the world average residual differences carrying a (expected)

\footnotetext{
${ }^{17}$ See previous footnote.
} 
positive sign and being statistically significant at the 1 percent level. Finally, and contrary to the existing literature, our evidence points to more significant problems in primary as opposed to in secondary school. We think that these findings suggest that the possibility of over-estimated human capital stocks, and its implications, should be investigated more extensively in the future.

One direction for future research is regarding the rates of return to investments in education. Because of the inherent difficulties in measuring the size and value of the stock of human capital, research has tried to estimate it using the rates of return. There is a long tradition of improving the estimation of these rates (Psacharopoulos, 1994 and references therein). It would be interesting to compare the social and private rates of return of 1989 with those of the present day. It would also be useful to know what their main determinants were before 1989 and what are they now. Furthermore, how large is the difference between the private and social rates in transition and how do these magnitudes compare with other regions? Another interesting line of inquiry would be regarding the determinants of occupational choice. Although we presumably know which incentives people have to choose the occupations they do today, how did they make these choices before 1990? Further, a closer look at the educational sector in a comprehensive sample of transition economies would be a quite relevant and informative exercise in terms of the issues outlined above. Finally, we should note that it is our hope that the unique data set we put together for this paper turns out to be helpful for future research in that these data provide a natural (and of course untapped) set of instruments. 


\section{REFERENCES}

Aghion, P. and Howitt, P. (1998). Endogenous Growth Theory, Cambridge, The MIT Press.

Ammermuller, A., Heijke, H. and Woessmann, L. (2003). 'Schooling Quality in Eastern Europe: Educational Production During Transition’, Discussion Paper 746, IZA, Bonn.

Azariadis, C. and Drazen, A. (1990). 'Threshold Externalities in Economic Development', Quarterly Journal of Economics, May, pp. 501-526.

Barro, R. and Lee, J. W. (1993). 'International Comparisons of Educational Attainment', Journal of Monetary Economics, December, pp. 363-394.

Barro, R and Lee, J.W. (1996). 'International Measures of Schooling Years and Schooling Quality', American Economic Review, May, pp. 218-223.

Barro, R. and Lee, J. W. (2001a). 'Schooling Quality in a Cross Section of Countries', Economica, 68, November, pp. 465-88.

Barro, R. and Lee, J. W. (2001b). 'International Data on Educational Attainment: Updates and Implications', Oxford Economic Papers, 53(3), July, pp. 541-63.

Becker, G. (1993). Human Capital: A Theoretical and Empirical Analysis with Special Reference to Education, Chicago, University of Chicago Press.

Behrman, J. and Rosenzweig, M. (1994). 'Caveat Emptor: Cross-Country Data on Education and the Labor Force', Journal of Development Economics, June, pp. 147-171.

Bils, M. and Klenow, P. (1997). 'Does Schooling Cause Growth or the Other Way Around?', University of Rochester and University of Chicago, mimeo, December.

Boeri, T. (2000). Structural change, welfare systems, and labour reallocation: Lessons from the transition of formerly planned economies, Oxford: Oxford University Press.

Bosca, J., de la Fuente, A. and Domenech, R. (1997). 'Human Capital and Growth: Theory Ahead of Measurement', mimeo, paper presented at the EEA meetings.

Campos, N. and Dabusinskas, A. (2003). 'So Many Rocket Scientists, So Few Marketing Clerks: Occupational Change During The Estonian Transition', Discussion Paper 3531, CEPR.

Card, D. and Krueger, A. (1996). 'Labor Markets Effects of School Quality: Theory and Evidence', NBER Working Paper No. 5450, January.

Czechoslovak Statistical Office, Czechoslovakia's Statistical Yearbook, various issues (1965, 1970, 1975, 1980, 1985, 1990), Prague.

Easterlin, R. (1981). 'Why isn't the Whole World Developed?', Journal of Economic History, March, pp. 1-19. 
German Democratic Republic Statistical Office, German Democratic Republic Statistical Yearbook, various issues $(1975,1980,1985,1990)$, Berlin.

Gundlach, E. (2001). 'Growth Effects of EU Membership: The Case of East Germany', IIASA, IR-01-035, Laxenburg, September.

Hanushek, E. (1979). 'Conceptual and Empirical Issues in the Estimation of Educational Production Functions', Journal of Human Resources, 14, Summer, pp. 351-88.

Hanushek, E. (1986). 'The Economics of Schooling: Production and Efficiency in Public Schools', Journal of Economic Literature, 24 (3), June, pp. 365-85.

Hanushek, E. and Kimko, D. (2000). 'Schooling, Labor Force Quality, and the Growth of Nations', American Economic Review 90(5), December, pp. 1184-1208.

Laporte, B. and Schweitzer, J. (1994). 'Education and Training', in Barr, N. (ed.), Labor Markets and Social Policy in Central and Eastern Europe: The Transition and Beyond, Washington and London, Oxford University Press (for the World Bank and LSE).

Lucas, R. (1988). 'On the Mechanics of Economic Development', Journal of Monetary Economics, 22, pp. 3-42.

Lucas, R. (1990). 'Why Doesn't Capital Flow from Rich to Poor Countries?', American Economic Review, May, pp. 92-96.

Mankiw, G., Romer, D. and Weil, D. (1992). 'A Contribution to the Empirics of Economic Growth', Quarterly Journal of Economics, May, pp. 407-437.

Mincer, J. (1958). 'Investment in Human Capital and Personal Income Distribution', Journal of Political Economy, August, pp. 281-302.

Mincer, J. (1996). 'Economic Development, Growth of Human Capital, and the Dynamics of the Wage Structure', Journal of Economic Growth, March, pp. 29-48.

Murphy, K., Schleifer, A. and Vishny, R. (1991). 'The Allocation of Talent: Implications for Growth', Quarterly Journal of Economics, May, pp. 503-530.

Nehru, V., Swanson, E. and Dubey, A. (1995). 'A New Database on Human Capital Stocks in Developing and Industrial Countries: Sources, Methodology and Results', Journal of Development Economics, June, pp. 379-401.

Nelson, R. and Phelps, E. (1966). 'Investment in Humans, Technological Diffusion and Economic Growth', American Economic Review, May, pp. 69-75.

Persson, T. and Tabellini, G. (1997). 'Political Economics and Macroeconomic Policy', NBER Working Paper No. 6329.

Pritchett, L. (1996). 'Where Has All the Education Gone?', Working Paper Series 1581, The World Bank, Washington, D.C. 
Pritchett, L. and Filmer, D. (1997). 'What Education Production Functions Really Show: A Positive Theory of Education Expenditures', mimeo, The World Bank, Washington, D.C.

Psacharopoulos, G. (1994). 'Returns to Investment in Education: A Global Update', World Development, pp. 1325-1343.

Rebelo, S. (1991). 'Long-Run Policy Analysis and Long Run Growth', Journal of Political Economy, 99 (3), pp. 500-521.

Romanian Statistical Office, Romanian Statistical Yearbook, various issues (1965, 1970, 1975, 1980, 1985, 1990), Bucharest.

Romer, P. (1990). 'Endogenous Technological Change', Journal of Political Economy, 98 (5), October, pp. S71-102.

Romer, P. (1993). 'Idea Gaps and Object Gaps in Economic Development', Journal of Monetary Economics, 32 (3), November, pp. 543-573.

Rosen, S. (1986). 'Human Capital', in The New Palgrave: A Dictionary of Economics, Macmillan Press, pp. 681-690.

Sachs, J. (1996). 'The Transition at Mid Decade', American Economic Review, May, pp. 128133.

Schultz, T. W. (1961). 'Investment in Human Capital', American Economic Review, March, pp. 1-17.

Schultz, T. W. (1975). 'The Value of the Ability to Deal with Disequilibria', Journal of Economic Literature, September.

Solow, R. (1997). Learning from “Learning by Doing”: Lessons for Economic Growth, Stanford: Stanford University Press.

Temple, J. (2001). 'Generalizations that aren't? Evidence on education and growth', European Economic Review, May, 45(4-6), pp. 905-918.

UNESCO, Statistical Yearbook, various issues (1960, 1966, 1971, 1976, 1981, 1986, 1991), Louvain, Belgium.

USSR Statistical Office, USSR Statistical Yearbook, various issues (1966, 1971, 1976, 1981, 1986, 1989), Moscow.

World Bank (1996), World Development Report 1996: From Plan to Market, Washington, Oxford University Press. 
Table 1. Primary Schooling Production Functions

\begin{tabular}{|c|c|c|c|}
\hline Dependent variable & PYR25 & PRI25 & PRIC25 \\
\hline Constant & $\begin{array}{l}1.048 * * * \\
(.268)\end{array}$ & $\begin{array}{c}2.04 * * * \\
(.382)\end{array}$ & $\begin{array}{l}1.599 * * * \\
(.409)\end{array}$ \\
\hline Pupil-teacher ratio (teapri) & $\begin{array}{l}-.341 * \\
(.187)\end{array}$ & $\begin{array}{c}-.564 * * \\
(.270)\end{array}$ & $\begin{array}{c}-.662 * * \\
(.286)\end{array}$ \\
\hline Repetition rate (reppri) & $\begin{array}{c}-168 * * * \\
(.045) \\
\end{array}$ & $\begin{array}{c}-.151 * * \\
(.064) \\
\end{array}$ & $\begin{array}{c}-.152 * * \\
(.069)\end{array}$ \\
\hline Drop-out rate (drop) & $\begin{array}{l}-.015 \\
(.036)\end{array}$ & $\begin{array}{l}-.012 \\
(.052)\end{array}$ & $\begin{array}{l}-.103^{*} \\
(.056)\end{array}$ \\
\hline $\begin{array}{l}\text { Av. real salary of primary school } \\
\text { teachers (salarp) }\end{array}$ & $\begin{array}{l}.506 * * * \\
(.143)\end{array}$ & $\begin{array}{c}1.08 * * * \\
(.205)\end{array}$ & $\begin{array}{l}1.183 * * * \\
(.219)\end{array}$ \\
\hline $\begin{array}{l}\text { Ratio of salarp to real p.c. GDP } \\
\text { (shsalp) }\end{array}$ & $\begin{array}{c}-.628 * * * \\
(.070) \\
\end{array}$ & $\begin{array}{c}-.651 * * * \\
(.101) \\
\end{array}$ & $\begin{array}{c}-.796 * * * \\
(.108) \\
\end{array}$ \\
\hline $\begin{array}{l}\text { Real govn. curr. educ. exp. per pupil } \\
\text { (geepri) }\end{array}$ & $\begin{array}{l}-.162 \\
(.135)\end{array}$ & $\begin{array}{c}.873 * * * \\
(.192) \\
\end{array}$ & $\begin{array}{c}-.797 * * * \\
(.206) \\
\end{array}$ \\
\hline No. obs. & 250 & 250 & 250 \\
\hline Adj. R-squared & 0.5937 & 0.2451 & 0.4165 \\
\hline \multicolumn{4}{|c|}{ Residuals and Tests for Differences in Residuals } \\
\hline$\varepsilon_{\mathrm{T}}$ & $\begin{array}{c}.182 \\
(.022) \\
\end{array}$ & $\begin{aligned} .299 \\
(.024)\end{aligned}$ & $\begin{array}{c}.364 \\
(.068)\end{array}$ \\
\hline$\varepsilon_{\mathrm{OECD}}$ & $\begin{array}{c}.019 \\
(.015)\end{array}$ & $\begin{array}{l}-.007 \\
(.034)\end{array}$ & $\begin{array}{c}.035 \\
(.040)\end{array}$ \\
\hline$\varepsilon_{\text {rest }}$ & $\begin{array}{l}-.012 \\
(.016)\end{array}$ & $\begin{array}{l}-.023 \\
(.022)\end{array}$ & $\begin{array}{l}-.019 \\
(.023)\end{array}$ \\
\hline$\varepsilon_{\mathrm{afr}}$ & $\begin{array}{l}-.073 \\
(.035)\end{array}$ & $\begin{array}{l}-.110 \\
(.048)\end{array}$ & $\begin{array}{l}-.137 \\
(.047)\end{array}$ \\
\hline$\varepsilon_{\text {asia }}$ & $\begin{array}{l}-.012 \\
(.027)\end{array}$ & $\begin{array}{l}-.053 \\
(.033)\end{array}$ & $\begin{array}{l}-.008 \\
(.041)\end{array}$ \\
\hline$\varepsilon_{\text {lac }}$ & $\begin{aligned} .048 \\
(.017)\end{aligned}$ & $\begin{array}{c}.123 \\
(.020) \\
\end{array}$ & $\begin{array}{c}.076 \\
(.023)\end{array}$ \\
\hline$\varepsilon_{\mathrm{T}}-\varepsilon_{\mathrm{OECD}}$ & $\begin{array}{l}.163 * * * \\
(0.000)\end{array}$ & $\begin{array}{l}.306^{* * * *} \\
(0.000)\end{array}$ & $\begin{array}{l}.328 * * * \\
(0.000)\end{array}$ \\
\hline$\varepsilon_{\mathrm{T}}-\varepsilon_{\text {rest }}$ & $\begin{array}{l}.195^{* * * *} \\
(0.000)\end{array}$ & $\begin{array}{l}.322 * * * \\
(0.000)\end{array}$ & $\begin{array}{l}.383 * * * \\
(0.000)\end{array}$ \\
\hline$\varepsilon_{\mathrm{T}}-\varepsilon_{\mathrm{afr}}$ & $\begin{array}{l}.256 * * * \\
(0.000)\end{array}$ & $\begin{array}{l}.409 * * * \\
(0.000)\end{array}$ & $\begin{array}{l}.501 * * * \\
(0.000)\end{array}$ \\
\hline$\varepsilon_{\mathrm{T}}-\varepsilon_{\text {asia }}$ & $\begin{array}{l}.194 * * * * \\
(0.000)\end{array}$ & $\begin{array}{l}.352 * * * \\
(0.000)\end{array}$ & $\begin{array}{l}.372 * * * \\
(0.000)\end{array}$ \\
\hline$\varepsilon_{\mathrm{T}}-\varepsilon_{\mathrm{lac}}$ & $\begin{array}{l}.134 * * * \\
(0.000)\end{array}$ & $\begin{array}{l}.175^{* * *} \\
(0.007)\end{array}$ & $\begin{array}{l}.288 * * * \\
(0.000)\end{array}$ \\
\hline
\end{tabular}

Notes:

1. All the variables are in logarithms.

2. The significance levels are denoted by $* * *(1 \%), * *(5 \%)$, and $*(10 \%)$.

3. $\varepsilon_{\mathrm{T}}$ represents the average residuals for the transition group; $\varepsilon_{\mathrm{OECD}}$ - the average residuals for OECD; $\varepsilon_{\text {rest }- \text { the }}$ average residuals for the rest of the countries; $\varepsilon_{\text {afr }}$ the average residuals for Africa; $\varepsilon_{\text {asia }}$ the average residuals for Asia; and, $\varepsilon_{\text {lac }}$ the average residuals for Latin America.

4. The second line for the reported difference of the average residuals represents the significance level of the difference. 
Table 2.

Dependent variable is

Average years of secondary schooling in total population, over 25 years

\begin{tabular}{|c|c|c|}
\hline & With Repetition Rate & Without Repetition Rate \\
\hline Constant & $\begin{array}{l}-0.286 \\
(.322) \\
\end{array}$ & $\begin{array}{c}-0.618 * * * \\
(0.216)\end{array}$ \\
\hline Pupil-teacher ratio (teasec) & $\begin{array}{c}-0.385 * * \\
(.151)\end{array}$ & $\begin{array}{l}-0.066 \\
(0.107)\end{array}$ \\
\hline $\begin{array}{l}\text { Real govn. current educ. Exp. per pupil } \\
\text { (geesec) }\end{array}$ & $\begin{array}{l}0.488 * * * \\
(0.062)\end{array}$ & $\begin{array}{l}0.584 * * * \\
(0.044)\end{array}$ \\
\hline Ratio of geesec to real p.c. GDP (shpups) & $\begin{array}{c}-0.619 * * * \\
(0.055)\end{array}$ & $\begin{array}{c}-0.836 * * * \\
(0.038)\end{array}$ \\
\hline Repetition rate (repsec) & $\begin{array}{c}0.123 * * \\
(0.050)\end{array}$ & \\
\hline No. obs. & 264 & 516 \\
\hline Adj R-square & 0.4951 & 0.5222 \\
\hline \multicolumn{3}{|c|}{ Residuals and Tests for Differences in Residuals } \\
\hline$\varepsilon_{\mathrm{T}}$ & $\begin{array}{l}-0.002 \\
(0.037)\end{array}$ & $\begin{array}{c}0.106 \\
(0.039)\end{array}$ \\
\hline$\varepsilon_{\mathrm{OECD}}$ & $\begin{array}{c}0.095 \\
(0.021)\end{array}$ & $\begin{array}{c}0.078 \\
(0.020)\end{array}$ \\
\hline$\varepsilon_{\text {rest }}$ & $\begin{array}{l}-0.011 \\
(0.029)\end{array}$ & $\begin{array}{l}-0.013 \\
(0.020)\end{array}$ \\
\hline$\varepsilon_{\mathrm{afr}}$ & $\begin{array}{l}-0.225 \\
(0.048)\end{array}$ & $\begin{array}{l}-0.182 \\
(0.031)\end{array}$ \\
\hline$\varepsilon_{\text {asia }}$ & $\begin{array}{c}0.035 \\
(0.037)\end{array}$ & $\begin{array}{c}0.044 \\
(0.029)\end{array}$ \\
\hline$\varepsilon_{\mathrm{lac}}$ & $\begin{array}{c}0.109 \\
(0.049)\end{array}$ & $\begin{array}{c}0.043 \\
(0.039)\end{array}$ \\
\hline$\varepsilon_{\mathrm{T}}-\varepsilon_{\mathrm{OECD}}$ & $\begin{array}{c}-0.097 * * \\
(0.012)\end{array}$ & $\begin{array}{c}0.028 \\
(0.261)\end{array}$ \\
\hline$\varepsilon_{\mathrm{T}}-\varepsilon_{\text {rest }}$ & $\begin{array}{c}0.009 \\
(0.425)\end{array}$ & $\begin{array}{c}0.119 * * * \\
(0.003)\end{array}$ \\
\hline$\varepsilon_{\mathrm{T}}-\varepsilon_{\mathrm{afr}}$ & $\begin{array}{l}0.223 * * * \\
(0.001)\end{array}$ & $\begin{array}{l}0.287 * * * \\
(0.000)\end{array}$ \\
\hline$\varepsilon_{\mathrm{T}}-\varepsilon_{\text {asia }}$ & $\begin{array}{l}-0.038 \\
(0.239)\end{array}$ & $\begin{array}{l}0.062 * \\
(0.09)\end{array}$ \\
\hline$\varepsilon_{\mathrm{T}}-\varepsilon_{\mathrm{lac}}$ & $\begin{array}{c}-0.111 * * \\
(0.030)\end{array}$ & $\begin{array}{c}0.063 \\
(0.127)\end{array}$ \\
\hline
\end{tabular}

Note:

1. All the variables are in logarithms.

2. The significance levels are denoted by $* * *(1 \%), * *(5 \%)$, and $*(10 \%)$.

3. $\varepsilon_{\mathrm{T}}$ represents the average residuals for the transition group; $\varepsilon_{\mathrm{OECD}}$ - the average residuals for OECD; $\varepsilon_{\text {rest }- \text { the }}$ average residuals for the rest of the countries; $\varepsilon_{\text {afr }}$ the average residuals for Africa; $\varepsilon_{\text {asia }}$ the average residuals for Asia; and, $\varepsilon_{\mathrm{lac}}$ the average residuals for Latin America.

4. The second line for the reported difference of the average residuals represents the significance level of the difference. 
Table 3.

Dependent variable is

Percentage of "secondary school attained" in the total population, over 25 years

\begin{tabular}{|c|c|c|}
\hline & With Repetition Rate & Without Repetition Rate \\
\hline Constant & $\begin{array}{c}0.981 * * * \\
(0.304)\end{array}$ & $\begin{array}{c}0.683 * * * \\
(0.212) \\
\end{array}$ \\
\hline Pupil-teacher ratio (teasec) & $\begin{array}{c}-0.419 * * * \\
(0.142)\end{array}$ & $\begin{array}{l}-0.126 \\
(0.106)\end{array}$ \\
\hline $\begin{array}{l}\text { Real govn. current educ. Exp. per pupil } \\
\text { (geesec) }\end{array}$ & $\begin{array}{c}0.453 * * * \\
(0.058)\end{array}$ & $\begin{array}{c}0.541 * * * \\
(0.044)\end{array}$ \\
\hline $\begin{array}{l}\text { Ratio of geesec to real p.c. GDP } \\
\text { (shpups) }\end{array}$ & $\begin{array}{c}-0.483 * * * \\
(0.052)\end{array}$ & $\begin{array}{c}-0.726 * * * \\
(0.038)\end{array}$ \\
\hline Repetition rate (repsec) & $\begin{array}{c}0.035 \\
(0.047)\end{array}$ & \\
\hline No. obs. & 264 & 516 \\
\hline Adj R-square & 0.4685 & 0.4744 \\
\hline \multicolumn{3}{|c|}{ Residuals and Tests for Differences in Residuals } \\
\hline$\varepsilon_{\mathrm{T}}$ & $\begin{array}{c}0.126 \\
(0.036)\end{array}$ & $\begin{array}{c}0.265 \\
(0.041)\end{array}$ \\
\hline$\varepsilon_{\mathrm{OECD}}$ & $\begin{array}{c}0.081 \\
(0.019)\end{array}$ & $\begin{array}{c}0.067 \\
(0.020)\end{array}$ \\
\hline$\varepsilon_{\text {rest }}$ & $\begin{array}{l}-0.012 \\
(0.027)\end{array}$ & $\begin{array}{l}-0.019 \\
(0.019)\end{array}$ \\
\hline$\varepsilon_{\mathrm{afr}}$ & $\begin{array}{l}-0.195 \\
(0.045)\end{array}$ & $\begin{array}{l}-0.177 \\
(0.030)\end{array}$ \\
\hline$\varepsilon_{\text {asia }}$ & $\begin{array}{c}0.040 \\
(0.037)\end{array}$ & $\begin{array}{c}0.046 \\
(0.029)\end{array}$ \\
\hline$\varepsilon_{\mathrm{lac}}$ & $\begin{array}{c}0.066 \\
(0.046)\end{array}$ & $\begin{array}{c}0.009 \\
(0.037)\end{array}$ \\
\hline$\varepsilon_{\mathrm{T}}-\varepsilon_{\mathrm{OECD}}$ & $\begin{array}{c}0.045 \\
(0.138)\end{array}$ & $\begin{array}{c}0.198 * * * \\
(0.000)\end{array}$ \\
\hline$\varepsilon_{\mathrm{T}}-\varepsilon_{\text {rest }}$ & $\begin{array}{c}0.138 * * * \\
(0.001)\end{array}$ & $\begin{array}{c}0.284 * * * \\
(0.000)\end{array}$ \\
\hline$\varepsilon_{\mathrm{T}}-\varepsilon_{\mathrm{afr}}$ & $\begin{array}{c}0.321 * * * \\
(0.000)\end{array}$ & $\begin{array}{c}0.443 * * * \\
(0.000)\end{array}$ \\
\hline$\varepsilon_{\mathrm{T}}-\varepsilon_{\text {asia }}$ & $\begin{array}{l}0.086^{* *} \\
(0.048)\end{array}$ & $\begin{array}{l}0.219 * * * \\
(0.001)\end{array}$ \\
\hline$\varepsilon_{\mathrm{T}}-\varepsilon_{\mathrm{lac}}$ & $\begin{array}{c}0.060 \\
(0.152)\end{array}$ & $\begin{array}{c}0.256^{* * * *} \\
(0.000)\end{array}$ \\
\hline
\end{tabular}

Note:

1. All the variables are in logarithms.

2. The significance levels are denoted by $* * *(1 \%), * *(5 \%)$, and * (10\%).

3. $\varepsilon_{\mathrm{T}}$ represents the average residuals for the transition group; $\varepsilon_{\mathrm{OECD}}$ - the average residuals for OECD; $\varepsilon_{\text {rest }- \text { the }}$ average residuals for the rest of the countries; $\varepsilon_{\text {afr }}$ the average residuals for Africa; $\varepsilon_{\text {asia }}$ the average residuals for Asia; and, $\varepsilon_{\text {lac }}$ the average residuals for Latin America.

4. The second line for the reported difference of the average residuals represents the significance level of the difference. 
Table 4.

Dependent variable is

Percentage of "secondary school complete" in total population, over 25 years

\begin{tabular}{|c|c|c|}
\hline & With Repetition Rate & Without Repetition Rate \\
\hline Constant & $\begin{array}{c}0.771 * * \\
(0.331) \\
\end{array}$ & $\begin{array}{c}0.496 * * \\
(0.238) \\
\end{array}$ \\
\hline Pupil-teacher ratio (teasec) & $\begin{array}{c}-0.581 * * * \\
(0.155)\end{array}$ & $\begin{array}{c}-0.262 * * \\
(0.119) \\
\end{array}$ \\
\hline $\begin{array}{l}\text { Real govn. current educ. Exp. per pupil } \\
\text { (geesec) }\end{array}$ & $\begin{array}{c}0.506^{* * *} \\
(0.064) \\
\end{array}$ & $\begin{array}{c}0.596 * * * \\
(0.049) \\
\end{array}$ \\
\hline $\begin{array}{l}\text { Ratio of geesec to real p.c. GDP } \\
\text { (shpups) }\end{array}$ & $\begin{array}{c}-0.637 * * * \\
(0.056)\end{array}$ & $\begin{array}{c}-0.894 * * * \\
(0.042) \\
\end{array}$ \\
\hline Repetition rate (repsec) & $\begin{array}{l}0.089^{*} \\
(0.052)\end{array}$ & \\
\hline No. obs. & 264 & 516 \\
\hline Adj R-square & 0.5296 & 0.5143 \\
\hline \multicolumn{3}{|c|}{ Residuals and Tests for Differences in Residuals } \\
\hline$\varepsilon_{\mathrm{T}}$ & $\begin{array}{l}0.132 \\
(.037) \\
\end{array}$ & $\begin{array}{l}0.284 \\
(.046) \\
\end{array}$ \\
\hline$\varepsilon_{\mathrm{OECD}}$ & $\begin{array}{c}0.080 \\
(0.024)\end{array}$ & $\begin{array}{c}0.069 \\
(0.023)\end{array}$ \\
\hline$\varepsilon_{\text {rest }}$ & $\begin{array}{c}0.000 \\
(0.029)\end{array}$ & $\begin{array}{l}-0.002 \\
(0.022)\end{array}$ \\
\hline$\varepsilon_{\mathrm{afr}}$ & $\begin{array}{l}-0.235 \\
(0.044)\end{array}$ & $\begin{array}{l}-0.238 \\
(0.031)\end{array}$ \\
\hline$\varepsilon_{\text {asia }}$ & $\begin{array}{c}0.078 \\
(0.038)\end{array}$ & $\begin{array}{c}0.110 \\
(0.032)\end{array}$ \\
\hline$\varepsilon_{\text {lac }}$ & $\begin{array}{c}0.080 \\
(0.051)\end{array}$ & $\begin{array}{c}0.011 \\
(0.042)\end{array}$ \\
\hline$\varepsilon_{\mathrm{T}}-\varepsilon_{\mathrm{OECD}}$ & $\begin{array}{c}0.052 \\
(0.119)\end{array}$ & $\begin{array}{l}0.214 * * * \\
(0.000)\end{array}$ \\
\hline$\varepsilon_{\mathrm{T}}-\varepsilon_{\text {rest }}$ & $\begin{array}{c}0.132 * * * \\
(0.002)\end{array}$ & $\begin{array}{l}0.285^{* * * *} \\
(0.000)\end{array}$ \\
\hline$\varepsilon_{\mathrm{T}}-\varepsilon_{\mathrm{afr}}$ & $\begin{array}{c}0.367 * * * \\
(0.000)\end{array}$ & $\begin{array}{l}0.522 * * * \\
(0.000)\end{array}$ \\
\hline$\varepsilon_{\mathrm{T}}-\varepsilon_{\text {asia }}$ & $\begin{array}{c}0.054 \\
(0.156)\end{array}$ & $\begin{array}{l}0.173 * * * \\
(0.001)\end{array}$ \\
\hline$\varepsilon_{\mathrm{T}}-\varepsilon_{\mathrm{lac}}$ & $\begin{array}{c}0.052 \\
(0.203)\end{array}$ & $\begin{array}{l}0.273 * * * \\
(0.000)\end{array}$ \\
\hline
\end{tabular}

Note:

1. All the variables are in logarithms.

2. The significance levels are denoted by $* * *(1 \%), * *(5 \%)$, and $*(10 \%)$.

3. $\varepsilon_{\mathrm{T}}$ represents the average residuals for the transition group; $\varepsilon_{\mathrm{OECD}}$ - the average residuals for OECD; $\varepsilon_{\text {rest }}$ - the average residuals for the rest of the countries; $\varepsilon_{\text {afr }}$ the average residuals for Africa; $\varepsilon_{\text {asia }}$ the average residuals for Asia; and, $\varepsilon_{\text {lac }}$ the average residuals for Latin America.

4. The second line for the reported difference of the average residuals represents the significance level of the difference. 
Fig. 1. Average schooling years in total population (over age 15), by region

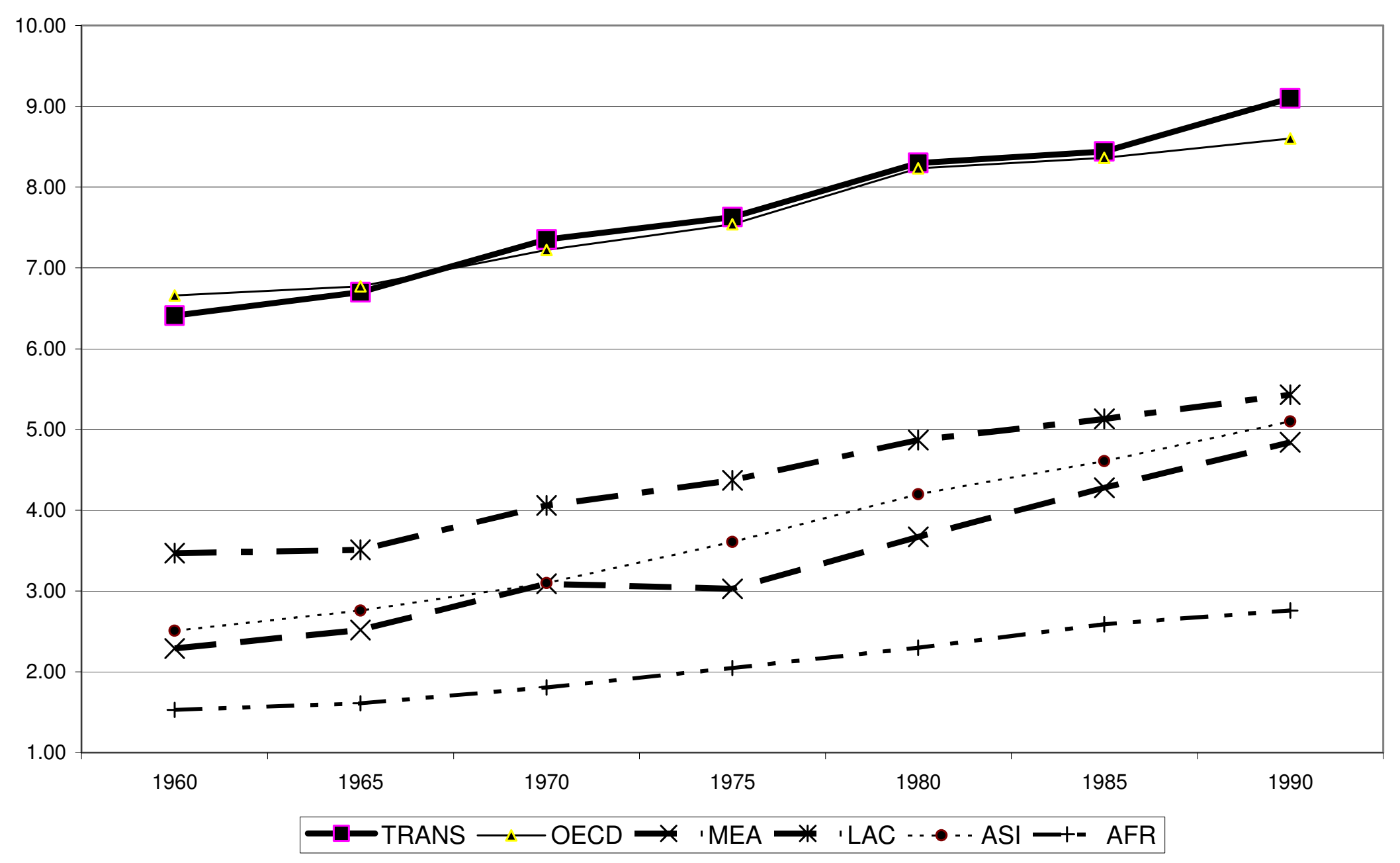


Fig. 2 Average pupil-teacher ratio at primary school, by region

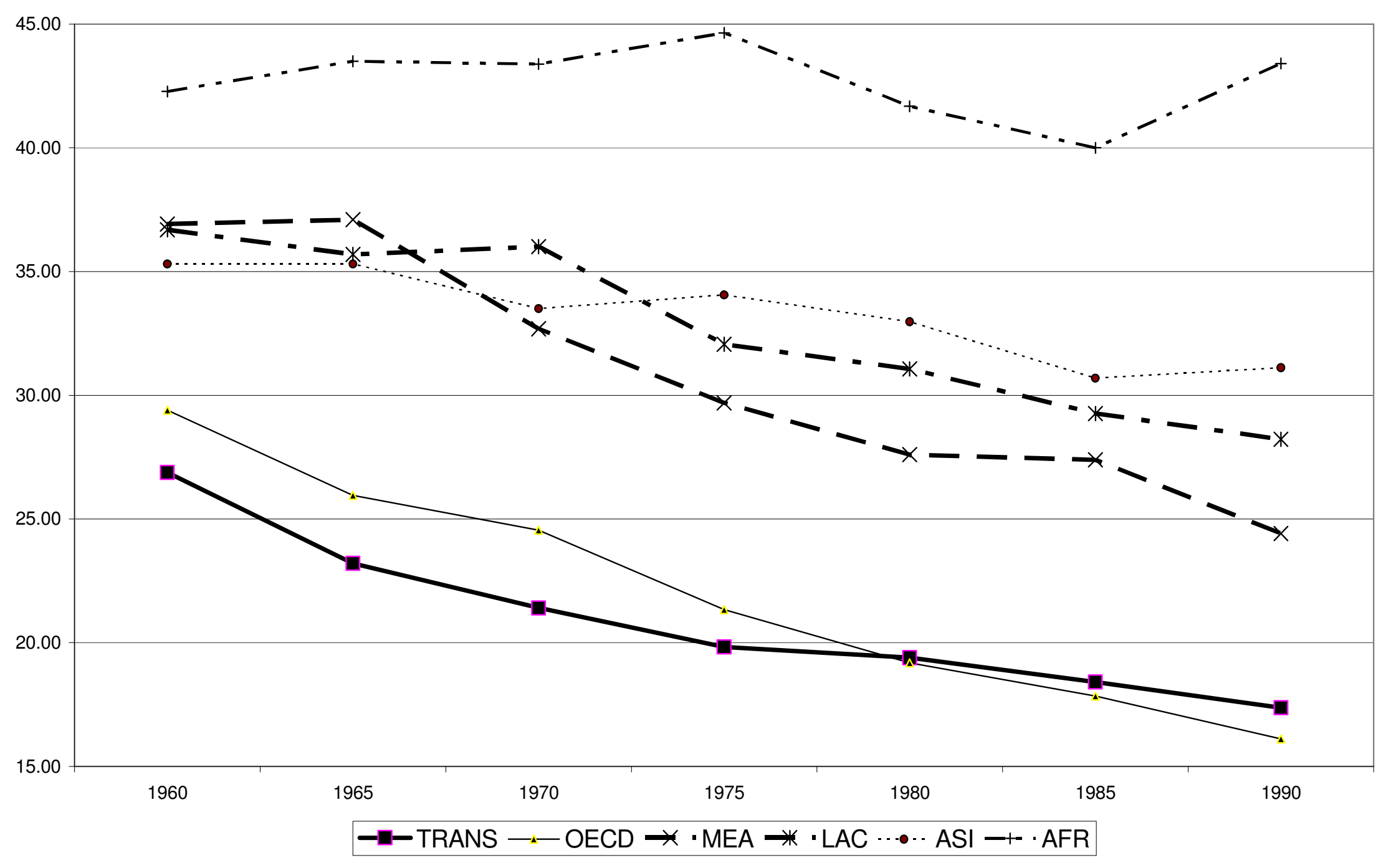


Fig. 3. Average pupil-teacher ratio at secondary school, by region

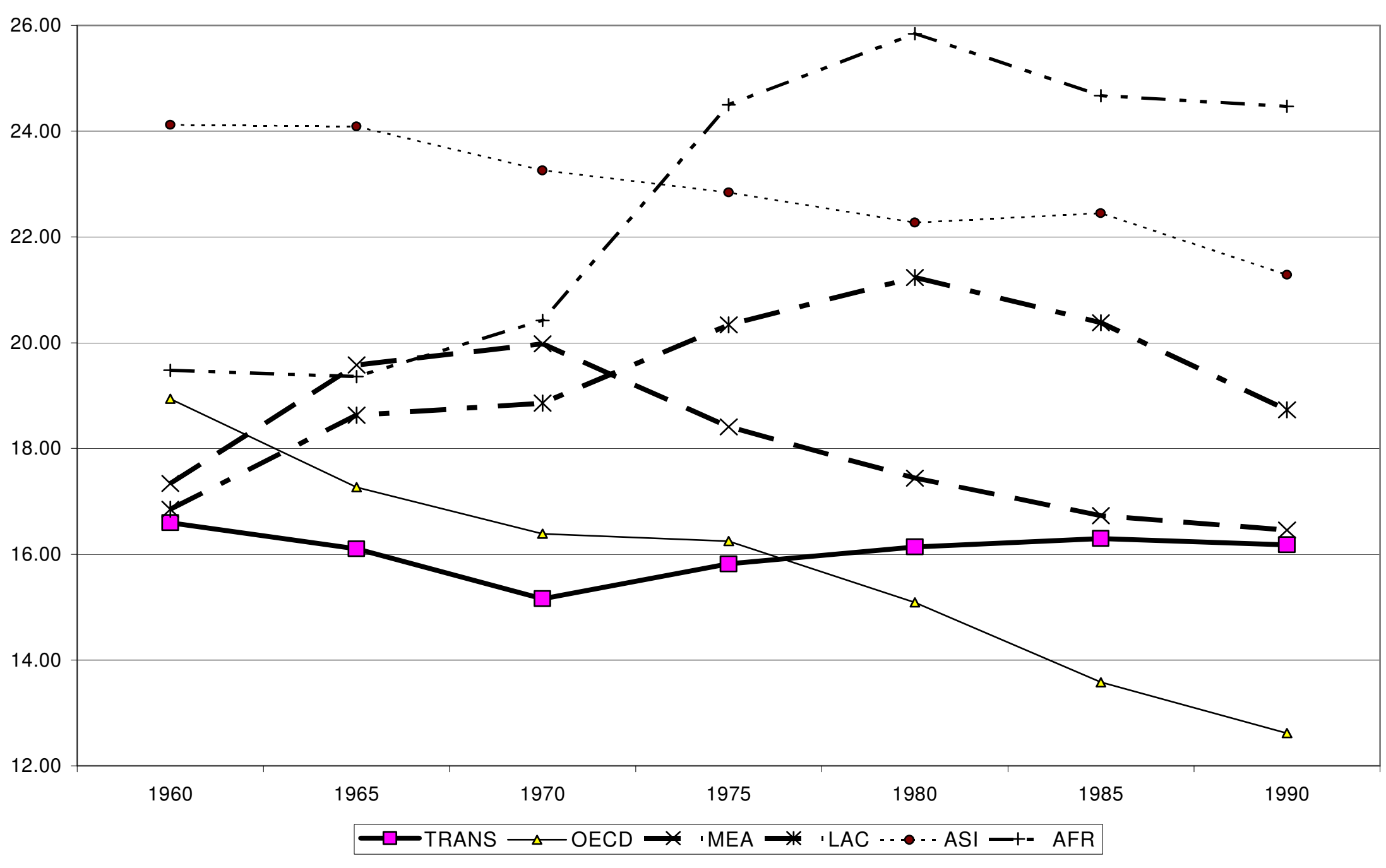


Fig. 4. Average repetition rates at primary school (in percentage), by region

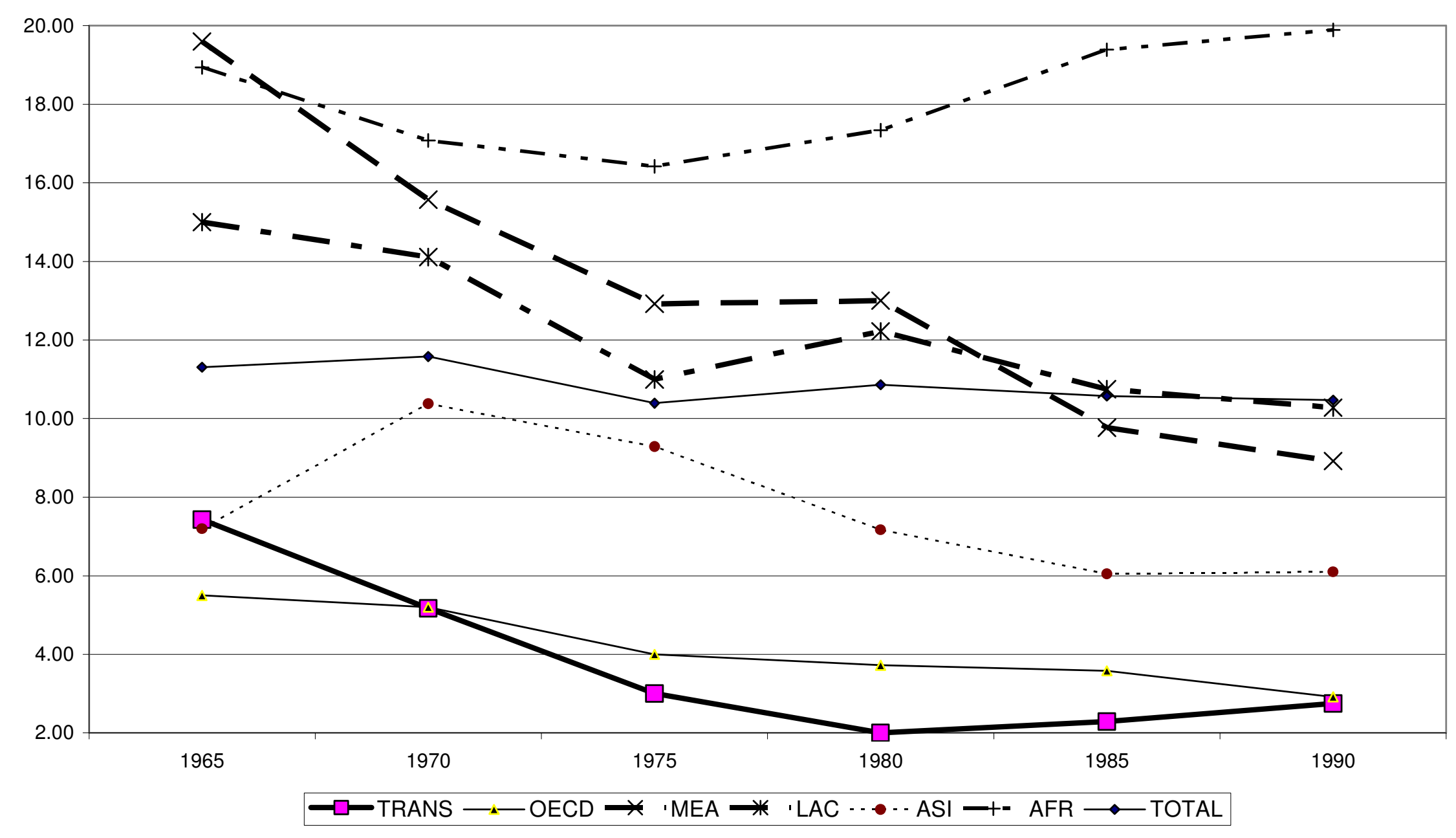


Fig. 5. Average repetition rates at secondary school (in percentage), by region

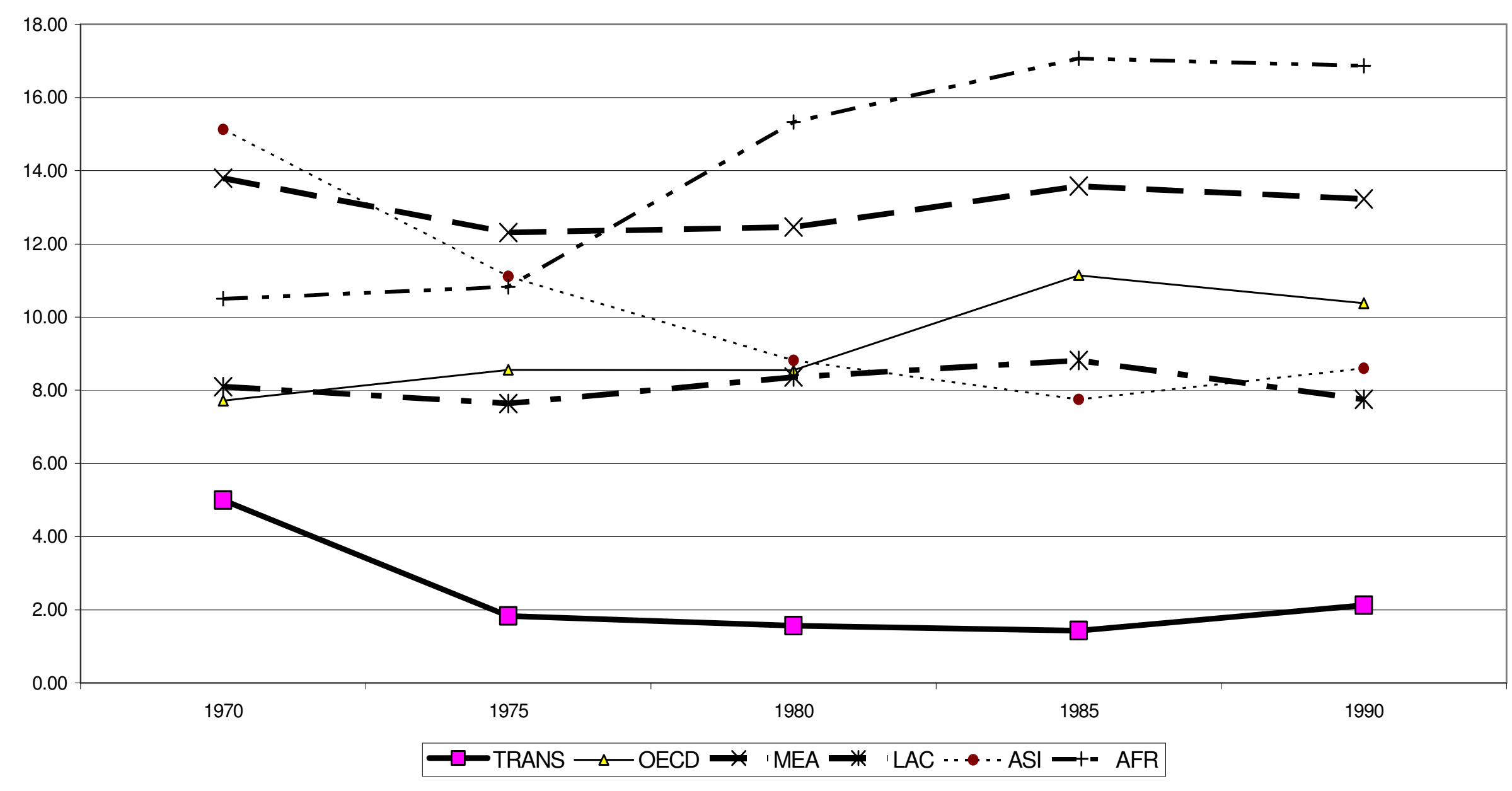

